International Scientific Organization http://iscientific.org/

Chemistry International

www.bosaljournals.com/chemint/

\title{
Ground water quality of selected areas of Punjab and Sind Provinces, Pakistan: Chemical and microbiological aspects
}

\author{
Farah Deeba, Naeem Abbas*, Muhammad Tahir Butt and Muhammad Irfan \\ Center for Environmental Protection Studies, PCSIR Laboratories Complex, Lahore Pakistan \\ *Corresponding author's E. mail: naeemchemist@gmail.com
}

\section{A R T I C L E I N F O}

Article type:

Research article

Article history:

Received September 2018

Accepted February 2019

October 2019 Issue

Keywords:

Groundwater

Ionic concentration

Trace elements

Microbiological count

WHO guidelines

Recommendations

\section{A B S T R A C T}

The assessment of groundwater is essential for the estimation of suitability of water for safe use. An attempt has been made to study the groundwater of selected areas of Punjab (Sheikhupura \& Sahiwal) and Sindh (Sindh, Jawar Dharki and Dharki), Pakistan. The results indicate that $\mathrm{pH}$, color and odor were all within limits of WHO that is $\mathrm{pH}$ ranges 6.5-8.5, colorless and odorless, respectively. The high values of suspended solids were observed in the Sindh-1 and Dharki samples. Microbiologically only Sahiwal and Jawar Dharki were found fit for drinking purpose. Trace metals analysis of Sheikhupura-1 and Sindh-1 showed that values do not fall within limits of WHO for Iron. The ionic concentration analysis showed that high bicarbonate $\left(\mathrm{HCO}_{3}^{-}\right)$, ions are present in the samples of Sahiwal and Dharki; Sindh-1 and Jawar Dharki samples showed very high concentration for chloride ions, all samples were satisfactory level for sulphate $\left(\mathrm{SO}_{4}{ }^{2-}\right)$, sodium, magnesium and phosphate ions except samples of Sindh-1 and Jawar Dharki. High concentration of calcium and potassium ions was observed in samples of Sindh-1, while all other samples were found fit for drinking purposes in respect of nitrate, nitrite and ammonium ions. The high concentration of Fluoride was found only in Sheikhupura-2 samples.

(C) 2019 International Scientific Organization: All rights reserved.

Capsule Summary: Drinking water quality of selected areas of Punjab (Sheikhupura \& Sahiwal) and Sindh (Sindh, Jawar Dharki and Dharki) were analyzed chemically and microbiologically to highlights the health risk.

Cite This Article As: F. Deeba, N. Abbas, M. T. Butt and M. Irfan. Ground water quality of selected areas of Punjab and Sind Provinces, Pakistan: Chemical and microbiological aspects. Chemistry International 5(4) (2019) 241-246. https://doi.org/10.5281/zenodo.2573563

\section{INTRODUCTION}

The quality of ground water is the resultant of all the processes and reactions that act on the water from the surroundings and it varies from place to place and with depth of the water table (Reid et al., 2003). Ground water has many unique characteristics which enable it to supply for public use. It is naturally found in sterile conditions, color and turbidity that can be consumed easily (Mondal et al., 2008).
Ground water is particularly accounts for the supply of safe drinking water in rural areas, where population is dispersed and infrastructure needed for high cost treatment and transportation of surface water (Langenegger, 1990). The problem of groundwater pollution in several parts of the country has become so acute that unless urgent steps are not taken, extensive groundwater resources may be damaged (Daud et al., 2017).

There are many reasons and sources of contamination to the ground water, e.g., land disposal of solid 
wastes, sewage disposal on land, agricultural activities, urban runoff and polluted surface water (Langenegger, 1990). The suitability of ground water has been examined with reference to WHO (2004) and NEQS (2002) standards (Khalafalla et al., 1993). The quality of groundwater in some parts of the Pakistan is changing as a result of human activities. Ground water is less susceptible to bacterial pollution than surface water because the soil and rocks through which groundwater flows screen out most of the bacteria. Bacteria, however, occasionally found their way to ground water, sometimes in dangerously high concentrations. But freedom from bacteria alone does not mean that the water is fit to drink. Many unseen dissolved minerals and organic constituents are present in groundwater in various concentrations. Most are harmless or even beneficial; though occurring infrequently, others are harmful, and few may be highly toxic. Water typically not considered fit for drinking if the quality of dissolved minerals exceeds $1000 \mathrm{mg} / \mathrm{L}$. Water with a few thousand $\mathrm{mg} / \mathrm{L}$ of dissolved minerals is classed as slightly saline, but sometimes used in areas where less-mineralized water is not available (Montcoudiol et al., 2015).

Due to unique chemical properties of water due to its polarity and hydrogen bonding, it has ability to suspend, dissolve, absorb and adsorb many different compounds. Thus water is not pure in nature, as it acquires contaminants from its surrounding and those arising from humans and animals as well as other biological activities (Chitmanat and Traichaiyaporn, 2010; Mendie, 2005). In recent years, the growth of industry, technology, population and water use has increased the stress upon both our land and water resources. Locally, the quality of groundwater has been degraded (Barik and Pattanayak, 2019; Dippong et al., 2019; Funk et al., 2019; Jang et al., 2019; Kalhor et al., 2019; Khan and Umar, 2019; Khanoranga and Khalid, 2019; Kilgour et al., 2019; Sefati et al., 2019; Shakerkhatibi et al., 2019). Municipal and industrial wastes and chemical fertilizers, herbicides, and pesticides not properly contained have entered in the soil, infiltered some aquifers, and degraded the ground water quality (Khattak et al., 2012; Riaz et al., 2018). Other pollution problems include sewage leakage, faulty septic-tank operation, and landfill leachates. In some coastal areas, intensive pumping of fresh ground water has caused salt water to intrude into freshwater aquifers (Woods, 1990). In present research work groundwater samples were analyzed of selected areas of Punjab (Sheikhupura \& Sahiwal) and Sindh (Sindh, Jawar Dharki and Dharki). The water quality parameters like $\mathrm{pH}$, color, odor, conductance, total suspended solids, trace metals $(\mathrm{Fe}, \mathrm{Cu}, \mathrm{B}, \mathrm{Ba}, \mathrm{Al}, \mathrm{Cr}, \mathrm{Cd}, \mathrm{Ni}, \mathrm{Mn}, \mathrm{Se}$ ), ionic concentration $\left(\mathrm{HCO}_{3}{ }^{-}, \mathrm{CO}_{3}{ }^{2-}, \mathrm{Cl}^{-}, \mathrm{SO}_{4}^{2-}, \mathrm{Na}^{+}, \mathrm{K}^{+}, \mathrm{Ca}^{2+}, \mathrm{Mg}^{2+}, \mathrm{NO}_{3}, \mathrm{NO}_{2}, \mathrm{NH}_{4}+, \mathrm{F}\right.$, $\mathrm{PO}_{4}{ }^{3}, \mathrm{CN}^{-}$) and for microbiological enumeration (total viable count, Total coliforms, Fecal coliforms E. coli). The data was analyzed with reference to WHO guidelines/ recommendations.

\section{MATERIAL AND METHODS}

\section{Samples collection}

Table 1: Sampling areas and sites

\begin{tabular}{|c|c|}
\hline Area & Provinces \\
\hline Sheikhupura Site 1 & Punjab \\
\hline Sheikhupura Site 2 & Punjab \\
\hline Sahiwal & Punjab \\
\hline Jawar Dharki Site 1 & Sindh \\
\hline Dharki & Sindh \\
\hline Sindh-1 & Sindh \\
\hline
\end{tabular}

The samples were collected from different locations of Punjab \& Sindh that are being extensively used for drinking and other domestic purposes. The water samples were taken from average depth 25-35 m. All water samples were collected in sterile glass Schott bottles (5 liter). While sampling some parameters like $\mathrm{pH}$ and conductance were measured in the field by using portable kits. For other parameters samples were stored and transported in a cool box kept below $4^{\circ} \mathrm{C}$ (APHA, 2005). The detailed chemical and microbiological analyses were performed as soon as the samples were carried to the laboratory.

\section{Microbiological analysis}

All samples were examined using standard methods (APHA, 2005; AOAC, 2005).

\section{Physicochemical analysis}

The physico-chemical parameters were determined according to procedures outlined in the Standard Methods for the Examination of Water and Wastewater (APHA, 2005). Turbidity was measured with a HACH 2100 P Turbidimeter. Sodium and potassium were measured by flame emission photometry, trace metals by atomic absorption spectrophotometer, calcium and magnesium by EDTA titration, sulphate by the turbidimetric method, colour by colour comparator and chloride by argentometric titration. Other analyses included alkalinity by strong acid titration method. Nutrients (nitrate-nitrogen and phosphatephosphorous) were determined using Dionex-80 ion analyzer and ammonium by direct nesslerization and spectrophotometric determination at $410 \mathrm{~nm}$. Fluoride by SPADNS method, total dissolved solids and suspended solids were measured gravimetrically after drying in an oven to a constant weight at $105^{\circ} \mathrm{C}$. The location of the sampling sites is shown in Table 1.

\section{RESULTS AND DISCUSSION}

The physical parameters of the collected samples are such as color and odor of all samples are within the WHO limits which is colorless and odorless and responses are shown in Table 2 along with WHO recommended limits (WHO, 2004). 
Table 2: Physical parameters of groundwater samples collected from different areas and sites

\begin{tabular}{lllllll}
\hline \multirow{2}{*}{ Location } & Depth & Color & Odor & $\mathrm{pH}$ & Conductivity & TSS \\
\cline { 2 - 6 } & $\mathrm{m}$ & & & $26{ }^{\circ} \mathrm{C}$ & $\mathrm{us} / \mathrm{cm}$ & $\mathrm{mg} / \mathrm{L}$ \\
\hline Sheikhupura Site 1 & 200 & colorless & Odorless & 8.23 & 679 & N.D* \\
Sheikhupura Site 2 & 460 & colorless & Odorless & 8.29 & 685 & N.D \\
Sahiwal Site 3 & 550 & colorless & Odorless & 7.81 & 887 & N.D \\
Sindh Site 1 & 150 & colorless & Odorless & 8.03 & 46300 & 36 \\
Jawar Dharki Site 2 & 600 & colorless & Odorless & 8.19 & 276 & N.D \\
Dharki Site 3 & 400 & colorless & Odorless & 8.44 & 12960 & 52 \\
WHO & & colorless & Odorless & $6.5-8.5$ & 14 & N.D \\
\hline
\end{tabular}

${ }^{*}$ N.D $=$ Not-detected

Table 3: Microbiological analysis of groundwater samples collected from different areas and sites

\begin{tabular}{lllllll}
\hline Location & $* \mathrm{~A}$ & $\mathrm{~B}$ & $\mathrm{C}$ & $\mathrm{D}$ & $\mathrm{E}$ & $\mathrm{F}$ \\
\hline Sheikhupura Site 1 & $90 \times 10^{3}$ & 94 & 70 & 33 & Detected & 17 \\
Sheikhupura Site 2 & $8.5 \times 10^{2}$ & 23 & 20 & 23 & N.D & 23 \\
Sahiwal Site 3 & $1.2 \times 10^{2}$ & N.D & N.D & N.D & N.D & N.D \\
Sindh Site 1 & $1.9 \times 10^{4}$ & 94 & 49 & 80 & Detected & 23 \\
Jawar Dharki Site 2 & $5.0 \times 10^{2}$ & N.D & N.D & N.D & N.D & N.D \\
Dharki Site 3 & $6.2 \times 10^{2}$ & 46 & 39 & 31 & Detected & 17 \\
WHO & - & 0.0 & 0.0 & 0.0 & N.D & 0.0 \\
\hline
\end{tabular}

${ }^{*} \mathrm{~A}=$ Viable count $/ \mathrm{mL}, \mathrm{B}=$ Total coliforms (MPN/100 mL), C $=$ Fecal coliforms (MPN $\left./ 100 \mathrm{~mL}\right), \mathrm{D}=$ E. coli $(\mathrm{MPN} / 100 \mathrm{~mL}), \mathrm{E}=$ Salmonella spp. $/ 25 \mathrm{~mL}$ and $\mathrm{F}=$ Pseudomonas Spp. $(\mathrm{MPN} / 100 \mathrm{~mL}),{ }^{*} \mathrm{~N} . \mathrm{D}=$ Not-detected

Table 4: Trace metals (mg/L) analyses of groundwater samples collected from different areas and sites

\begin{tabular}{lllllllllll}
\hline Location & $\mathrm{Fe}$ & $\mathrm{Cu}$ & $\mathrm{B}$ & $\mathrm{Ba}$ & $\mathrm{Al}$ & $\mathrm{Cr}$ & $\mathrm{Cd}$ & $\mathrm{Ni}$ & $\mathrm{Mn}$ & $\mathrm{Se}$ \\
\hline Sheikhupura Site 1 & 0.78 & $\mathrm{~N} . \mathrm{D}$ & 0.214 & $\mathrm{~N} . \mathrm{D}$ & $\mathrm{N} . \mathrm{D}$ & $\mathrm{N} . \mathrm{D}$ & 0.02 & 0.25 & 0.1 & N.D \\
Sheikhupura Site 2 & 0.1 & N.D & 0.4 & 0.2 & N.D & N.D & N.D & N.D & 0.02 & N.D \\
Sahiwal Site 3 & 0.06 & N.D & 1.6 & 0.1 & N.D & N.D & N.D & N.D & N.D & N.D \\
Sindh Site 1 & 0.35 & N.D & 0.47 & 0.1 & N.D & N.D & N.D & 0.25 & N.D & N.D \\
Jawar Dharki Site 2 & 0.22 & 0.055 & 0.4 & N.D & N.D & N.D & N.D & 0.01 & N.D & N.D \\
Dharki Site 3 & 0.32 & N.D & N.D & N.D & N.D & N.D & N.D & N.D & 0.02 & N.D \\
WHO & 0.3 & 1 & 1 & 1 & 0.02 & 0.1 & 0 & 0.05 & 0.1 & N.D \\
\hline
\end{tabular}

N.D = Not-detected

The $\mathrm{pH}$ of all samples is also fall within the recommended limits (6.5-8.5) and total suspended solids should be zero; but two samples of groundwater (Sindh-1 and Dharki) contained TSS 36.0 and $52.0 \mathrm{mg} / \mathrm{L}$ respectively. In this study, the conductivity of the collected samples is observed above permissible limits of WHO i.e., 46300 and 12960 us/cm of Sindh-1 and Dharki groundwater samples. Overall results of the physical analysis showed that Sindh-1 and Dharki are not fit for human consumption while other samples can be used for drinking purposes.
According to WHO recommendations, the drinking water must have zero total coliforms, fecal coliforms and E. coli (WHO, 2004). The results of microbiological analysis are shown in Table 3 that show that Sheikhupura site-1, Sheikhupura site-2, Sindh-1, and Dharki groundwater is not fit for drinking purposes. Total coliform counts give a general indication of the sanitary condition of a water supply, which include bacteria that are found in the soil, in water that has been influenced by surface water and human/animal waste (Atherholt et al., 2003). 
Table 5: Ionic concentration $(\mathrm{mg} / \mathrm{L})$ analyses of groundwater samples collected from different areas and sites

\begin{tabular}{|c|c|c|c|c|c|c|c|c|c|c|c|c|c|c|}
\hline Location & $\mathrm{HCO}_{3}^{-}$ & $\mathrm{CO}_{3}^{--}$ & $\mathrm{Cl}^{-}$ & $\mathrm{SO}_{4}^{--}$ & $\mathrm{Na}^{+}$ & $\mathrm{K}^{+}$ & $\mathrm{Ca}^{++}$ & $\mathrm{Mg}^{++}$ & $\mathrm{NO}_{3}-$ & $\mathrm{NO}_{2}^{-}$ & $\mathrm{NH}_{4}{ }^{+}$ & $\mathrm{F}^{-}$ & $\mathrm{PO}_{4}^{--}$ & $\mathrm{CN}^{-}$ \\
\hline $\begin{array}{l}\text { Sheikhupura } \\
\text { Site } 1\end{array}$ & 261.8 & N.D & 35 & 57.6 & 116 & 1.5 & 8 & 3.4 & N.D & N.D & N.D & 0.15 & N.D & N.D \\
\hline $\begin{array}{l}\text { Sheikhupura } \\
\text { Site } 2\end{array}$ & 225 & N.D & 27.2 & 24 & 95 & 5 & 14.06 & 8.54 & 5 & N.D & N.D & 28 & N.D & N.D \\
\hline Sahiwal Site 3 & 319 & N.D & 80.97 & 45 & 85 & 6 & 40 & 15.5 & N.D & N.D & 0.85 & 0.25 & 0.25 & N.D \\
\hline Sindh Site 1 & 233.6 & N.D & 12140 & 6140 & 2480 & 110 & 820 & 1116.5 & 1.18 & N.D & N.D & N.D & 55 & N.D \\
\hline $\begin{array}{l}\text { Jawar Dharki } \\
\text { Site } 2\end{array}$ & 121.39 & N.D & 19.9 & 44 & 10 & 2 & 16 & 14.58 & N.D & N.D & N.D & 2.5 & 50 & N.D \\
\hline Dharki Site 3 & 583.77 & N.D & 2603 & 960 & 1800 & 40 & 102 & 191 & N.D & N.D & 1.02 & 5 & N.D & N.D \\
\hline WHO & 300 & N.D & $\begin{array}{l}200- \\
600\end{array}$ & 250 & 250 & 50 & 250 & 50 & 50 & 50 & 50 & 1.5 & N.D & N.D \\
\hline
\end{tabular}

*N.D $=$ Not-detected

E. coli is the major species in the fecal coliform group. Of the five general groups of bacteria that comprise the total coliforms, only E. coli is generally not found growing and reproducing in the environment (Crysup and Mott, 2001; Stewart, 2012). Data shows that only Sahiwal and Jawar Dharki were fit microbiologically while all the other sample having values above WHO recommended level, so they were unfit for drinking purpose.

The results of trace metals are shown in Table 4, according to this study due to slightly high concentration of $\mathrm{Cd}$, the Sheikhupura site-1 sample is not potable; slightly high concentration of iron is observed in Sheikhupura site2 , Sindh site-1 and Darki samples. The concentration of $\mathrm{Ni}$ is found in Sheikhupura site- 1 and Sindh site- 1 . The chromium compounds bind to soil are not likely to migrate to ground water. They are very persistent in water as sediments. There is a high potential for accumulation of chromium in aquatic life (Singh and Lawrence, 2007).

Naturally occurring contaminants are present in the rocks and sediments. As ground water flows through sediments, metals such as iron and manganese are dissolved and may later be found in high concentrations in water. Industrial discharges, urban activities, agriculture, groundwater pumping and disposal of waste all can affect groundwater quality. Contaminates from leaking fuel tanks or fuel or toxic chemicals spills may enter the groundwater and contaminate the aquifer (Kjoller et al., 2004).

The result of ionic concentration analysis (Table 5) shows that very high Bicarbonates $\left(\mathrm{HCO}_{3}\right)$ ions are present in the samples of Sahiwal and Dharki; while all samples are found satisfactory in respect of Carbonates and Cyanide (CN) concentrations. Sindh-1 and Jawar Dharki samples have showed very high concentration for chloride ions, all samples were satisfactory level for sulphate $\left(\mathrm{SO}_{4}{ }^{2-}\right)$, sodium $(\mathrm{Na})$, Magnesium (Mg) and phosphate ions except groundwater samples of Sindh-1 and Jawar dharki. There was high concentration of calcium and potassium ions in samples of Sindh-1 while all samples were found fit for drinking purposes in respect of nitrate, nitrite and ammonium ions. Slightly high concentration of fluoride is found in Jawar Dharki and Dharki groundwater samples, but high concentration level was found in Sheikhupura site2 sample. These findings revealed that the water quality is has been changed in comparison of previous studies from the selected area and with the passage of time the water quality is degrading. So far, there is need to monitor the drinking water quality, which is helpful to avoid the negative health impacts (Boone et al., 2019; Brunner et al., 2019; Charuaud et al., 2019; Khanoranga and Khalid, 2019; Mintenig et al., 2019; Mohammed, 2019; Nnorom et al., 2019; Perrin et al., 2019; Rocha-Melogno et al., 2019; RuizBeviá and Fernández-Torres, 2019; Shakoor et al., 2019; Sharma et al., 2019; Uppal et al., 2019; Xiao et al., 2019).

\section{CONCLUSIONS}

The study has provided information about the water quality status of different locations of the Punjab and Sindh provinces of Pakistan. The results indicated that $p \mathrm{H}$, color and odor were all within their natural background levels of 6.5-8.5, colorless and odorless respectively, but the conductivity of all samples were observed out of recommended limits of WHO. The high total suspended solids were observed in the Sindh-1 and Dharki samples. Microbiologically only Sahiwal and Jawar Dharki are found fit for drinking purpose as according to the WHO guidelines / recommendations for drinking water the total coliforms, fecal coliforms and E. coli must be absent. Hence, the microbiological quality of all the water sources was poor due to direct contamination by animal and human activities. Trace metals analysis of Dharki and Sindh-1 has showed that they do not fall within limits of WHO for Iron, while $\mathrm{Cd}$ and $\mathrm{Ni}$ concentration is slightly high in Sheikhupura site-1 groundwater sample. In case of $\mathrm{Mn}$, Sheikhupura site-1, Sheikhupura site-2 and Dharki were observed to be slightly high.

\section{REFERENCES}


APHA, 2005. Standard methods for the examination of water and wastewater. American Public Health Association (APHA): Washington, DC, USA.

Atherholt, T., Feerst, E., Hovendon, B., Kwak, J., Rosen, J.D., 2003. Evaluation of indicators of fecal contamination in groundwater. Journal-American Water Works Association 95, 119-131.

Barik, R., Pattanayak, S.K., 2019. Assessment of groundwater quality for irrigation of green spaces in the Rourkela city of Odisha, India. Groundwater for Sustainable Development 8, 428-438.

Boone, J.S., Vigo, C., Boone, T., Byrne, C., Ferrario, J., Benson, R., Donohue, J., Simmons, J.E., Kolpin, D.W., Furlong, E.T., Glassmeyer, S.T., 2019. Per- and polyfluoroalkyl substances in source and treated drinking waters of the United States. Science of the Total Environment 653, 359-369.

Brunner, A.M., Dingemans, M.M.L., Baken, K.A., van Wezel, A.P., 2019. Prioritizing anthropogenic chemicals in drinking water and sources through combined use of mass spectrometry and ToxCast toxicity data. Journal of Hazardous Materials 364, 332-338.

Charuaud, L., Jarde, E., Jaffrezic, A., Thomas, M.-F., Le Bot, B., 2019. Veterinary pharmaceutical residues from natural water to tap water: Sales, occurrence and fate. Journal of Hazardous Materials 361, 169-186.

Chitmanat, C., Traichaiyaporn, S., 2010. Spatial and temporal variations of physical-chemical water quality and some heavy metals in water, sediments and fish of the Mae Kuang River, Northern Thailand. International Journal of Agriculture and Biology 12, 816-820.

Crysup, K., Mott, J., 2001. Fecal coliform, enterococci and E. coli as indicators of water quality in the Creek Bay watershed, Corpus Christi, Texas, General Meeting of the American Society for Microbiology, pp. 20-24.

Daud, M., Nafees, M., Ali, S., Rizwan, M., Bajwa, R.A., Shakoor, M.B., Arshad, M.U., Chatha, S.A.S., Deeba, F., Murad, W., 2017. Drinking water quality status and contamination in Pakistan. BioMed Research International 2017, 1-18.

Dippong, T., Mihali, C., Hoaghia, M.-A., Cical, E., Cosma, A., 2019. Chemical modeling of groundwater quality in the aquifer of Seini town - Someș Plain, Northwestern Romania. Ecotoxicology and Environmental Safety 168, 88-101.

Funk, S.P., Duffin, L., He, Y., McMullen, C., Sun, C., Utting, N., Martin, J.W., Goss, G.G., Alessi, D.S., 2019. Assessment of impacts of diphenyl phosphate on groundwater and near-surface environments: Sorption and toxicity. Journal of Contaminant Hydrology 221, 50-57.

Jang, C.-S., Kuo, Y.-M., Chen, S.-K., 2019. Assessment of shallow groundwater use for irrigating park trees in the metropolitan Taipei Basin according to variability conditions of water quality. Journal of Hydrology 2, 100013.

Kalhor, K., Ghasemizadeh, R., Rajic, L., Alshawabkeh, A., 2019. Assessment of groundwater quality and remediation in karst aquifers: A review. Groundwater for Sustainable Development 8, 104-121.

Khalafalla, G., El-Gizawy, S., Ensaf, I., 1993. Bacteriological quality of various drinking water sources. Egyptian Journal of Applied Science 8, 809-822.

Khan, I., Umar, R., 2019. Environmental risk assessment of coal fly ash on soil and groundwater quality, Aligarh, India. Groundwater for Sustainable Development 8, 346357.

Khanoranga, Khalid, S., 2019. An assessment of groundwater quality for irrigation and drinking purposes around brick kilns in three districts of Balochistan province, Pakistan, through water quality index and multivariate statistical approaches. Journal of Geochemical Exploration 197, 1426.

Khattak, M.A., Ahmed, N., Qazi, M.A., Izhar, A., Ilyas, S., Chaudhary, M.N., Khan, M.S.A., Iqbal, N., 2012. Evaluation of ground water quality for irrigation and drinking purposes of the areas adjacent to Hudiara industrial drain, Lahore, Pakistan. Pakistan Journal of Agriculture Sciences 49, 549-556.

Kilgour, B., Mahaffey, A., Brown, C., Hughes, S., Hatry, C., Hamilton, L., 2019. Variation in toxicity and ecological risks associated with some oil sands groundwaters. Science of the Total Environment 659, 1224-1233.

Kjoller, C., Postma, D., Larsen, F., 2004. Groundwater acidification and the mobilization of trace metals in a sandy aquifer. Environmental Science \& Technology 38, 2829-2835.

Langenegger, O., 1990. Ground water quality in rural areas of Western Africa, UNDP project. INT/81/026, pp. 10.

Mendie, U., 2005. The theory and practice of clean water production for domestic and industrial use: Purified and package water. Lagos: Lacto-Medals Publishers.

Mintenig, S.M., Löder, M.G.J., Primpke, S., Gerdts, G., 2019. Low numbers of microplastics detected in drinking water from ground water sources. Science of the Total Environment 648, 631-635.

Mohammed, A.N., 2019. Resistance of bacterial pathogens to calcium hypochlorite disinfectant and evaluation of the usability of treated filter paper impregnated with nanosilver composite for drinking water purification. Journal of Global Antimicrobial Resistance 16, 28-35.

Mondal, N., Singh, V., Saxena, V., Prasad, R., 2008. Improvement of groundwater quality due to fresh water ingress in Potharlanka Island, Krishna delta, India. Environmental Geology 55, 595-603.

Montcoudiol, N., Molson, J., Lemieux, J.-M., 2015. Groundwater geochemistry of the Outaouais Region (Québec, Canada): a regional-scale study. Hydrogeology Journal 23, 377-396.

Nnorom, I.C., Ewuzie, U., Eze, S.O., 2019. Multivariate statistical approach and water quality assessment of natural springs and other drinking water sources in Southeastern Nigeria. Heliyon 5, e01123.

Perrin, Y., Bouchon, D., Delafont, V., Moulin, L., Héchard, Y., 2019. Microbiome of drinking water: A full-scale spatio- 
temporal study to monitor water quality in the Paris distribution system. Water Research 149, 375-385.

Reid, D.C., Edwards, A.C., Cooper, D., Wilson, E., Mcgaw, B.A., 2003. The quality of drinking water from private water supplies in Aberdeenshire, UK. Water Research 37, 245254.

Riaz, U., Abbas, Z., Mubashir, M., Jabeen, M., Zulqadar, S.A., Javeed, Z., Ashraf, M., Qamar, M.J., 2018. Evaluation of Ground Water Quality for Irrigation Purposes and Effect On Crop Yields: A GIS Based Study of Bahawalpur. Pakistan Journal of Agricultural Research 31, 29-36.

Rocha-Melogno, L., Yoo, R., Broesicke, O., Kallergis, A., Garcia, J., Herbas, E., Torrez-Daza, A., Johnson, A., Boey, D., Beard, V., Frisbie, S.H., Murcott, S., Brown, J., 2019. Rapid drinking water safety estimation in cities: Piloting a globally scalable method in Cochabamba, Bolivia. Science of the Total Environment 654, 1132-1145.

Ruiz-Beviá, F., Fernández-Torres, M.J., 2019. Effective catalytic removal of nitrates from drinking water: An unresolved problem? Journal of Cleaner Production 217, 398-408.

Sefati, Z., Khalilimoghadam, B., Nadian, H., 2019. Assessing urban soil quality by improving the method for soil environmental quality evaluation in a saline groundwater area of Iran. CATENA 173, 471-480.

Shakerkhatibi, M., Mosaferi, M., Pourakbar, M., Ahmadnejad, M., Safavi, N., Banitorab, F., 2019. Comprehensive investigation of groundwater quality in the north-west of Iran: Physicochemical and heavy metal analysis. Groundwater for Sustainable Development 8, 156-168.

Shakoor, M.B., Niazi, N.K., Bibi, I., Shahid, M., Saqib, Z.A., Nawaz, M.F., Shaheen, S.M., Wang, H., Tsang, D.C.W., Bundschuh, J., Ok, Y.S., Rinklebe, J., 2019. Exploring the arsenic removal potential of various biosorbents from water. Environment International 123, 567-579.

Sharma, B.M., Bečanová, J., Scheringer, M., Sharma, A., Bharat, G.K., Whitehead, P.G., Klánová, J., Nizzetto, L., 2019. Health and ecological risk assessment of emerging contaminants (pharmaceuticals, personal care products, and artificial sweeteners) in surface and groundwater (drinking water) in the Ganges River Basin, India. Science of the Total Environment 646, 1459-1467.

Singh, D.S.H., Lawrence, J., 2007. Groundwater quality assessment of shallow aquifer using geographical information system in part of Chennai City, Tamil Nadu. Journal-Geological Society of India 69, 1067.

Stewart, E.J., 2012. Growing unculturable bacteria. Journal of Bacteriology 194, 4151-4160.

Uppal, J.S., Zheng, Q., Le, X.C., 2019. Arsenic in drinking water - Recent examples and updates from Southeast Asia. Current Opinion in Environmental Science \& Health https://doi.org/10.1016/j.coesh.2019.01.004

WHO, 2004. World Health Organization. Guidelines for drinking-water quality: recommendations. World Health Organization.
Woods, L., 1990. Groundwater quality in the Nore River Bain, Republic of Ireland. Unpublished M. Sc. dissertation, University College, London.

Xiao, J., Wang, L., Deng, L., Jin, Z., 2019. Characteristics, sources, water quality and health risk assessment of trace elements in river water and well water in the Chinese Loess Plateau. Science of the Total Environment 650, 2004-2012.

Visit us at: http://bosaljournals.com/chemint/ Submissions are accepted at: editorci@bosaljournals.com 